\title{
Infra-red transillumination stereophotography of the iris in Fuchs's heterochromic cyclitis
}

\author{
M. SAARI, I. VUORRE, AND H. NIEMINEN \\ From the University Eye Hospital, Oulu, Finland
}

SUMMARY The structural pattern of the iris in 13 patients with Fuchs's heterochromic cyclitis (FHC) was studied by infra-red transillumination stereophotography. All eyes with FHC showed atrophic changes of the iris. Extensive iris atrophy appeared as light, even translucence of the iris, associated in some cases with occasional dense small patches or pigment clumps. Moderate punctate, patchy or radiate, or extensive atrophy of the sphincter muscle was seen in all eyes with FHC. Radial contraction folds of Schwalbe, structural folds of Schwalbe, and circular contraction folds on the posterior surface of the iris were visualised in few eyes with FHC, whereas they were seen in most contralateral eyes. The results suggest that infra-red transillumination stereophotography can be used as a cilagnostic method in FHC.

Heterochromic cyclitis, a condition characterised by a chronic, quiet cyclitis with keratic precipitates, stromal atrophy of the iris, a change in the colour of the iris, the absence of synechiae, the development of a complicated cataract, and vitreous opacities, was established as a clinical entity by Fuchs (1906). In Fuchs's heterochromic cyclitis (FHC) the architecture of the trabeculae of the iris is lost, the relief of the anterior surface is diminished, on slit-lamp examination the whole tissue shows a rarefaction and transparency, at the pigment border the deep pigmentary layer appears defective and moth-eaten in places, and transillumination through the pupil may demonstrate hole-like areas of atrophy of the pigment epithelium (Duke-Elder and Perkins, 1966). We describe here our observations on the structural pattern of the iris in FHC studied by infra-red transillumination stereophotography (Saari and Nieminen, 1976).

\section{Patients and methods}

SELECTION OF PATIENTS

The clinical characteristics of the 13 patients with FHC included in this study are shown in Table 1. Four patients were males and nine were females; the age range was from 12 to 71 years, with a mean age of 39 years. Eleven patients had heterochromia, which in 1 case (12) was so slight as to be difficult to see. A boy developed heterochromia at the age of 12 years (case 4) after 1 year's monthly follow-up. One patient (case 3 ) had inverse heterochromia,

Address for reprints: Dr M. Saari, University Eye Hospital, Kajaanintie 50, SF-90220 Oulu 22, Finland. with the affected iris appearing darker than its fellow. In 2 cases ( 2 and 10$)$ no heterochromia was found. The right eye was affected in 6 cases and the left in 7 cases. All patients had keratic precipitates. A slight aqueous flare was seen in 11 cases; the aqueous humour was clear in 2 cases. Some aqueous cells were seen in 11 cases. Biomicroscopy showed rarefaction of the iris stroma, with changes in the relief of the anterior surface of the iris in all cases. The lens was completely opaque in 4 patients (cases $1,3,7$, and 11), and 2 of them (cases 1 and 7) underwent cataract extraction; all other patients had opacities in the posterior cortex or subcapsular region of the lens. Fine opacities in the vitreous were seen in 7 cases. One patient (case 2) had a transient spontaneous sharp rise of the intraocular pressure up to $40 \mathrm{mmHg}, 1$ patient (case 9) developed corticosteroid-induced transient ocular hypertension, and 2 patients (cases 3 and 8 ) showed a quiet, secondary glaucoma. All cases with heterochromia which might be secondary to other pathological conditions of the eye than FHC were excluded. One patient (case 1) had coloboma of the iris and of the choroid in the contralateral eye.

\section{PHOTOGRAPHIC EXAMINATION}

Colour photographs and the infra-red transillumination stereophotographs of the iris (Saari and Nieminen, 1976) were taken of both eyes of all patients. For transillumination of the iris a highintensity light from an electronic flash unit was led through a filter transmitting only the infra-red region of light (Kodak Wratten filter No. 87) via glassfibre optics through the lateral side of the 
Table 1 Clinical data in 13 cases of Fuchs's heterochromic cyclitis

\begin{tabular}{|c|c|c|c|c|c|c|c|c|c|c|}
\hline Case & Age & $\operatorname{Sex}$ & Heterochromia & $\begin{array}{l}\text { Cyclitic } \\
\text { eye }\end{array}$ & $\begin{array}{l}\text { Keratic } \\
\text { precipitates }\end{array}$ & $\begin{array}{l}\text { Aqueous } \\
\text { flare }\end{array}$ & $\begin{array}{l}\text { Aqueous } \\
\text { cells }\end{array}$ & $\begin{array}{l}\text { Atrophy of } \\
\text { iris stroma }\end{array}$ & $\begin{array}{l}\text { Complicated } \\
\text { cataract }\end{array}$ & $\begin{array}{c}\text { Vitreous } \\
\text { opacities }\end{array}$ \\
\hline 1 & 43 & $\mathbf{M}$ & + & $\mathbf{R}$ & + & \pm & + & + & + & - \\
\hline 2 & 38 & $\mathbf{F}$ & - & $\mathbf{L}$ & + & + & + & + & + & + \\
\hline 3 & 59 & $\mathbf{F}$ & + & $\mathbf{R}$ & + & + & + & + & + & + \\
\hline 4 & 12 & $\mathbf{M}$ & + & $\mathbf{L}$ & + & \pm & + & \pm & + & + \\
\hline 5 & 15 & $\mathbf{M}$ & + & $\mathbf{L}$ & + & \pm & + & + & + & - \\
\hline 6 & 57 & $\mathbf{F}$ & + & $\mathbf{R}$ & + & - & - & + & + & + \\
\hline 7 & 71 & $\mathbf{F}$ & + & $\mathbf{L}$ & + & + & - & + & + & + \\
\hline 8 & 51 & $\mathbf{F}$ & + & $\mathbf{L}$ & + & \pm & + & + & + & - \\
\hline 9 & 35 & $\mathbf{F}$ & + & $\mathbf{L}$ & + & \pm & + & \pm & + & + \\
\hline 10 & 27 & $\mathbf{F}$ & - & $\mathbf{L}$ & + & + & + & + & + & - \\
\hline 11 & 42 & $\mathbf{M}$ & + & $\mathbf{R}$ & + & - & + & + & + & - \\
\hline 12 & 23 & $\mathbf{F}$ & \pm & $\mathbf{R}$ & + & \pm & + & \pm & + & + \\
\hline 13 & 30 & $\mathbf{F}$ & + & $\mathbf{R}$ & + & \pm & + & + & + & - \\
\hline
\end{tabular}

$+=$ present $; \quad \pm=$ minimal finding; $-=$ absent.

Table 2 Infra-red transillumination stereophotographic findings of the iris in Fuchs's heterochromic cyclitis (FHC) and in the contralateral eye (CE)

\begin{tabular}{|c|c|c|c|c|c|c|c|c|c|c|}
\hline \multirow{3}{*}{ Case no. } & \multirow{2}{*}{\multicolumn{2}{|c|}{ Structural pattern }} & \multirow{2}{*}{\multicolumn{2}{|c|}{ Sphincter muscle }} & \multicolumn{6}{|c|}{ Posterior surface of the iris } \\
\hline & & & & & $R C F S$ & & $S F S$ & & $C C F$ & \\
\hline & $F H C$ & $C E$ & $F H C$ & $C E$ & $F H C$ & $C E$ & $F H C$ & $C E$ & $F H C$ & $C E$ \\
\hline 1 & $\begin{array}{l}\text { Extensive atrophy, } \\
\text { iridotomy }\end{array}$ & $\begin{array}{l}\mathrm{N}(\mathrm{WD}), \\
\text { coloboma }\end{array}$ & $\overline{\text { (Extensive atrophy) }}$ & + & - & - & - & + & - & + \\
\hline 2 & $\begin{array}{l}\text { Extensive atrophy, } \\
\text { occasional dense } \\
\text { patches }\end{array}$ & $\mathbf{N}(W D)$ & $\overline{\text { (Remnants of SM) }}$ & + & - & + & - & + & - & - \\
\hline 3 & Extensive atrophy & $\mathbf{N}(\mathbf{W D})$ & $\begin{array}{l}+ \\
\text { (Radiate atrophy) }\end{array}$ & + & + & - & - & + & - & + \\
\hline 4 & Moderate atrophy & $\mathbf{N}(R D)$ & $\begin{array}{l}\text { (Extensive atrophy) } \\
+\end{array}$ & + & - & + & + & + & + & + \\
\hline 5 & Moderate atrophy & $\mathbf{N}(R D)$ & (Punctate atrophy) & + & - & $\div$ & + & + & - & + \\
\hline 6 & Extensive atrophy & $\mathbf{N}(\mathbf{S A})$ & (Remnants of SM) & + & - & - & + & + & - & - \\
\hline 7 & Extensive atrophy & $\mathbf{N}(\mathbf{S A})$ & $\begin{array}{l}\text { (Extensive radiate } \\
\text { atrophy) } \\
+\end{array}$ & + & - & - & - & + & - & - \\
\hline 8 & $\begin{array}{l}\text { Moderate atrophy, } \\
\text { small iris cyst }\end{array}$ & $\mathrm{N}(\mathrm{WD})$ & (Atrophic patches) & + & - & + & $\div$ & + & - & + \\
\hline 9 & $\begin{array}{l}\text { Moderate atrophy, } \\
\text { small iris cyst }\end{array}$ & $\mathbf{N}(W D)$ & $\begin{array}{l}+ \\
\text { (Punctate atrophy) } \\
+\end{array}$ & + & + & + & $\div$ & + & + & + \\
\hline 10 & $\begin{array}{l}\text { Moderate atrophy, } \\
\text { two iris cysts }\end{array}$ & $N(W D)$ & (Punctate atrophy) & + & + & + & + & + & + & + \\
\hline 11 & Extensive atrophy & $\mathbf{N}(W D)$ & $\begin{array}{l}\overline{\text { (Extensive radiate }} \\
\quad \text { atrophy) } \\
+\end{array}$ & + & - & + & - & + & - & + \\
\hline 12 & Moderate atrophy & $\begin{array}{l}\text { N(WD) } \\
\text { iris cyst }\end{array}$ & (Atrophic patches) & + & - & + & + & + & - & + \\
\hline 13 & $\begin{array}{l}\text { Extensive atrophy, } \\
\text { pigment clumps }\end{array}$ & $N(W D)$ & (Punctate atrophy) & + & + & + & + & + & - & + \\
\hline
\end{tabular}


globe. Stereoscopic pairs of photographs were taken with a standard Zeiss stereo slit-lamp camera on Kodak high-speed infra-red black-and-white film. The stereophotographs were examined with a stereoscopic viewer (Condor T-22, Ushikata, Tokyo, Japan). In each infra-red transillumination stereophotograph we recorded the structural pattern of the iris, the presence of atrophic changes in the whole iris and especially in the sphincter muscle, and the visualisation of the radial contraction folds

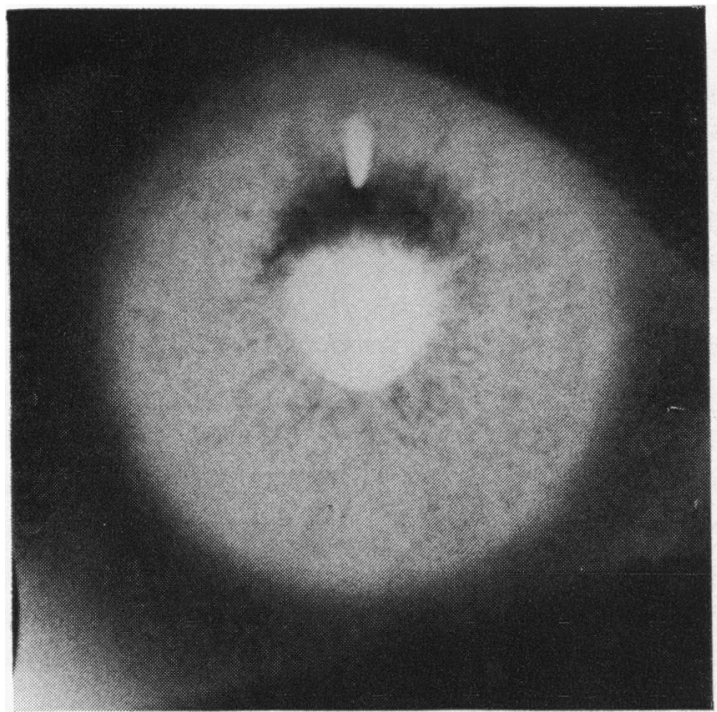

Fig. 1a (left)

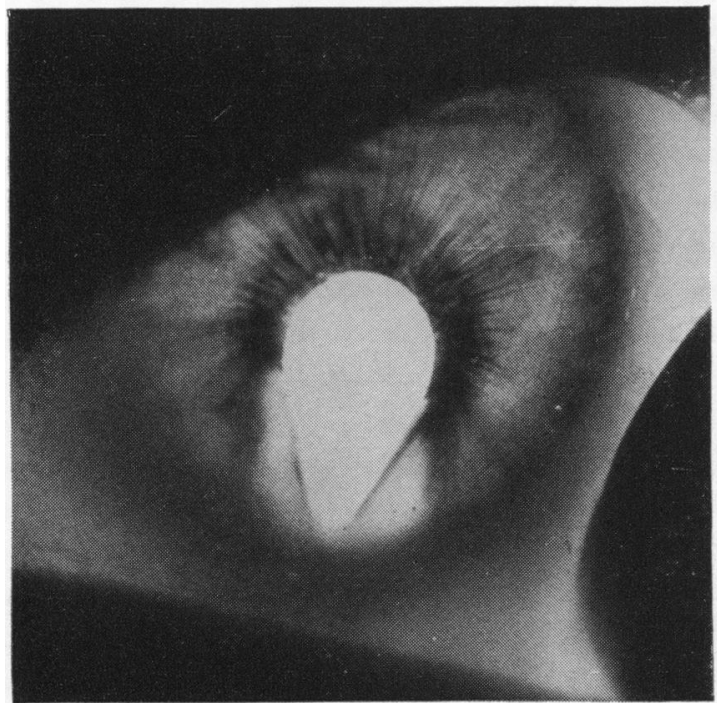

Fig. 1b (left) of Schwalbe, of structural folds of Schwalbe, and of the circular contraction folds on the posterior surface of the iris, and compared them with the findings in the contralateral eye.

\section{Results}

In the 13 cases studied 7 eyes with FHC showed extensive atrophy of the iris (Table 2). The most extensive stage of the iris atrophy (cases 1 and 11)

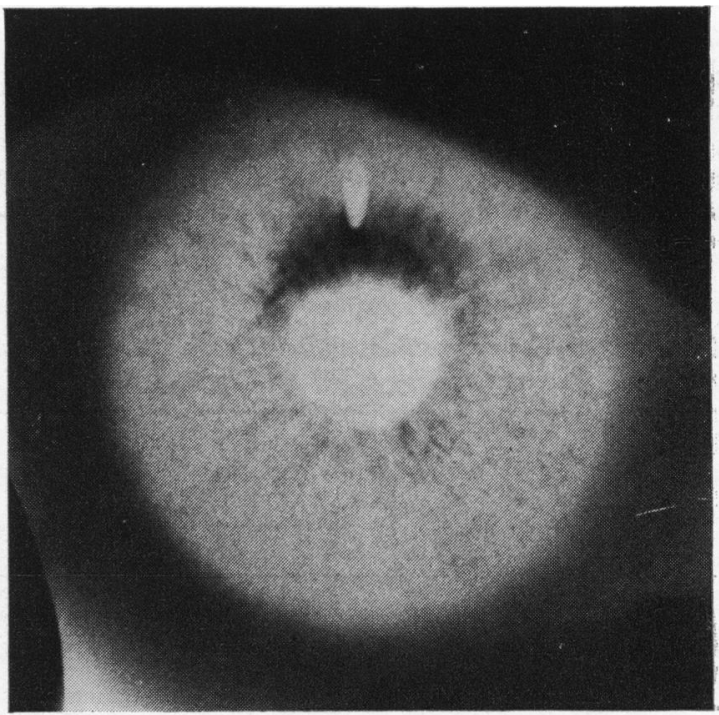

Fig. 1a (right)

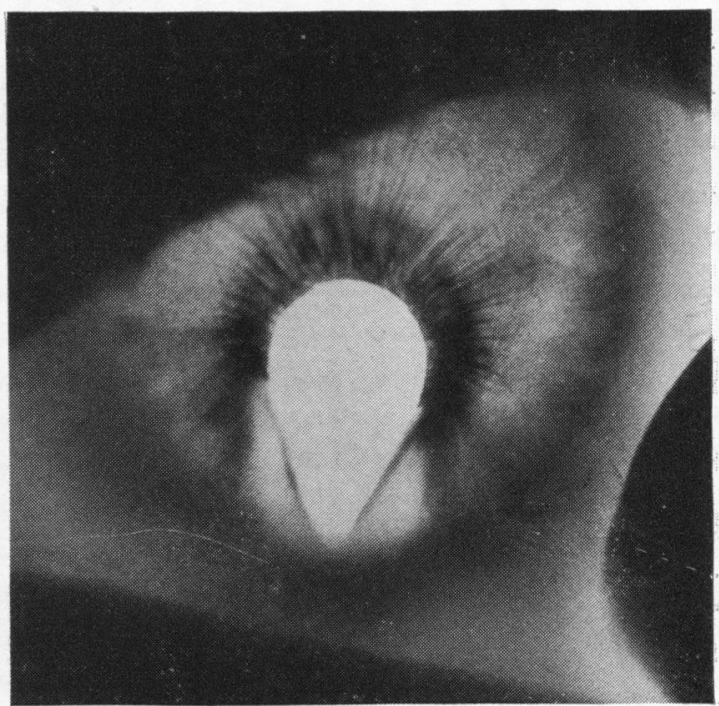

Fig. 1b (right)

Fig. 1 Infra-red transillumination stereophotographs of iris in FHC (case 1). Right eye shows extensive iris atrophy, and iridotomy hole at $12 o^{\prime}$ clock. Left eye shows congenital iris coloboma but otherwise normal structural pattern of iris: 
appeared in infra-red transillumination stereophotographs as light, even translucence of the iris (Figs. 1, 2). In 2 cases ( 2 and 6 ) with extensive iris atrophy remnants of the sphincter muscle and occasional dense patches in the ciliary part of the iris were seen. In 1 case (13) punctate atrophy was present in the sphincter muscle and some pigment clumps were seen in the ciliary part of the iris showing marked atrophy (Fig. 3). In 2 cases the sphincter area showed radial sectors with extensive

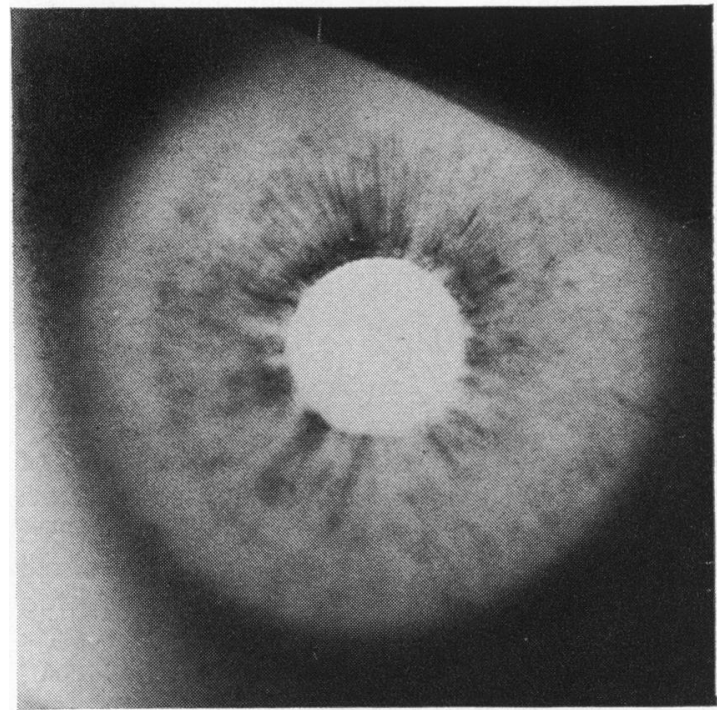

Fig. 2a (left)

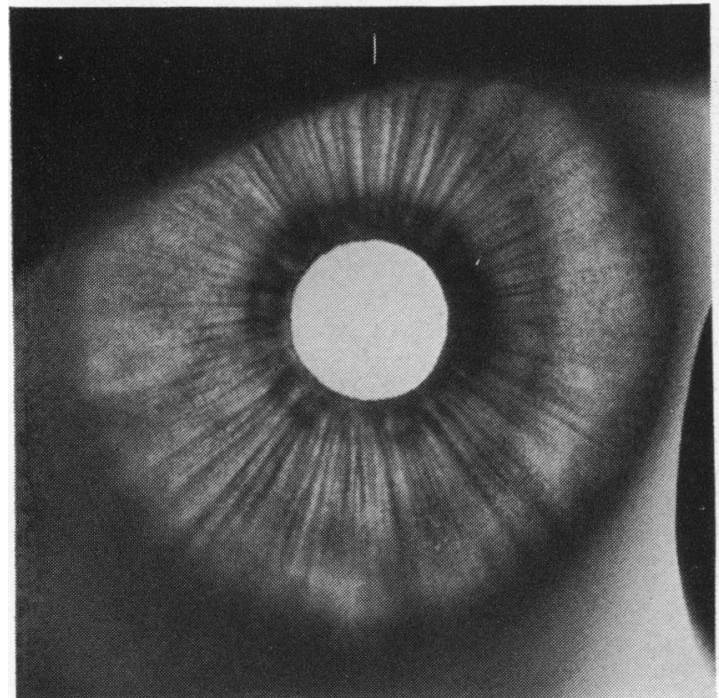

Fig. 2b (left) (case 7) or moderate (case 3) atrophy, and the ciliary part of the iris was moth-eaten in appearance (Figs. 4, 5). All eyes with development of completely opaque lens showed extensive iris atrophy. After cataract extraction the iridotomy appeared as a white hole in the infra-red transillumination stereophotographs (Fig. 1A). Six eyes with FHC showed moderate atrophy of the iris (Table 2). A small iris cyst was seen in 2 eyes with FHC (cases 8 and 9), and 2 iris cysts in 1 (case 10). Except for the eye

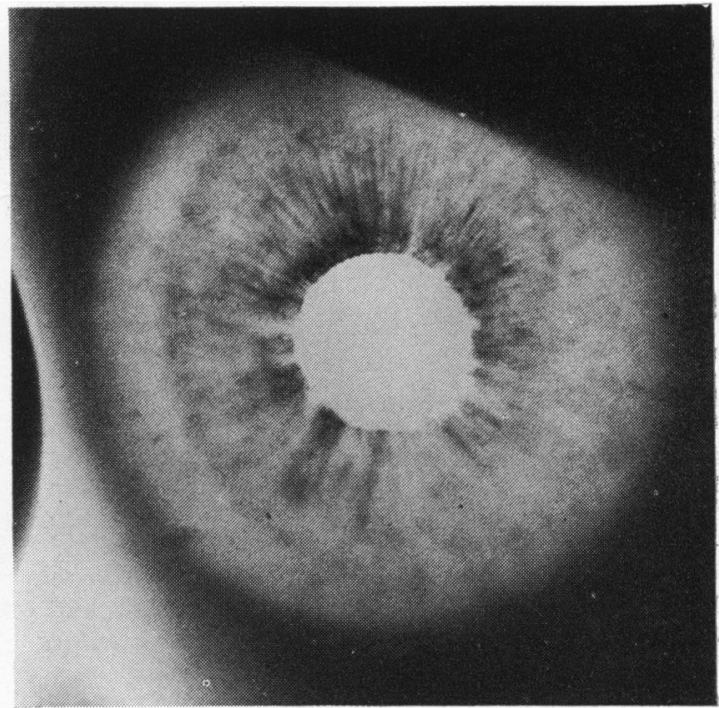

Fig. 2a (right)

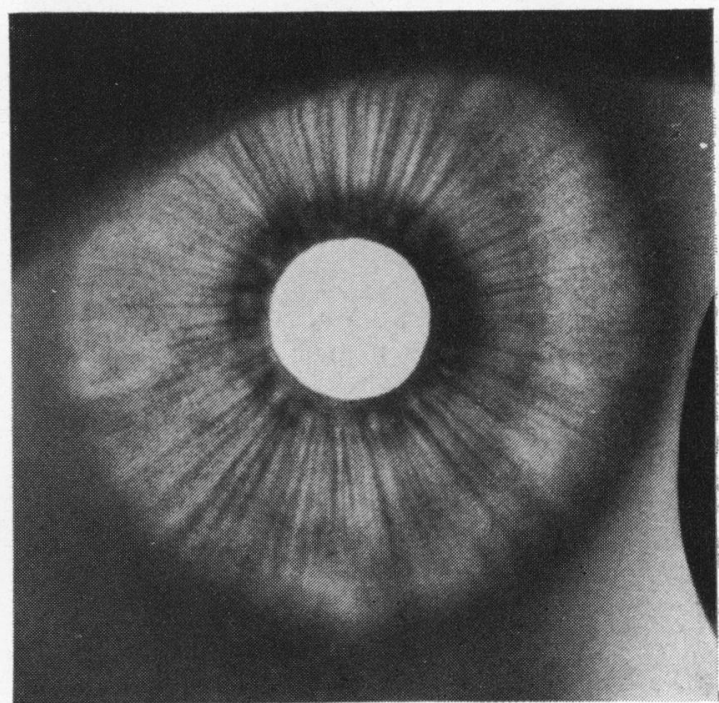

Fig. 2b (right)

Fig. 2 Infra-red transillumination stereophotographs of iris in FHC (case 11). Right eye shows extensive iris atrophy. Left eye has normal structural pattern of iris 
with congenital coloboma of the iris (case 1), and 1 eye with a small iris cyst (case 12), all contralateral eyes showed normal structural pattern of the iris, which was well developed in 9 cases, rather dense in 2 (12- and 15-year-old patients), and somewhat

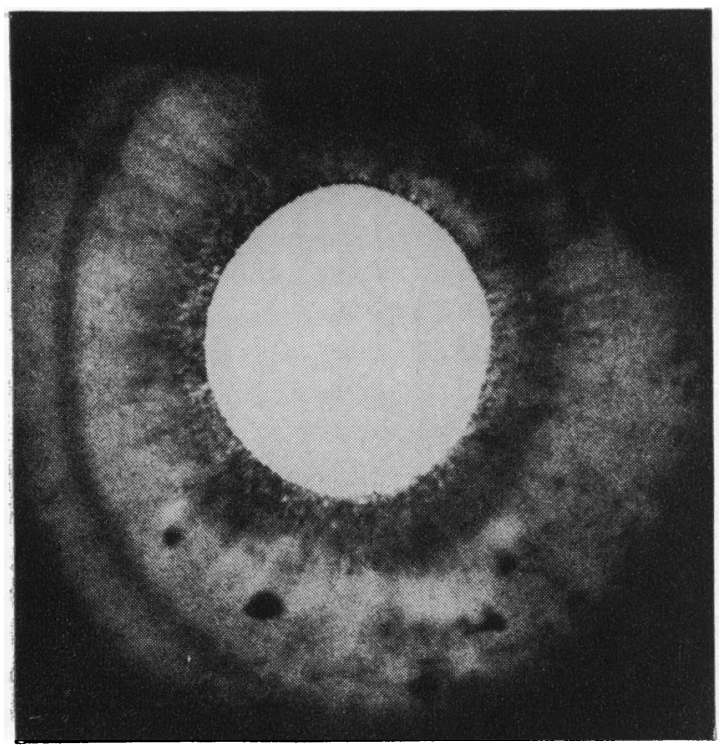

Fig. 3 Infra-red transillumination photograph of iris in FHC (case 13) showing punctate atrophy of sphincter muscle and pigment clumps in ciliary part with extensive atrophy

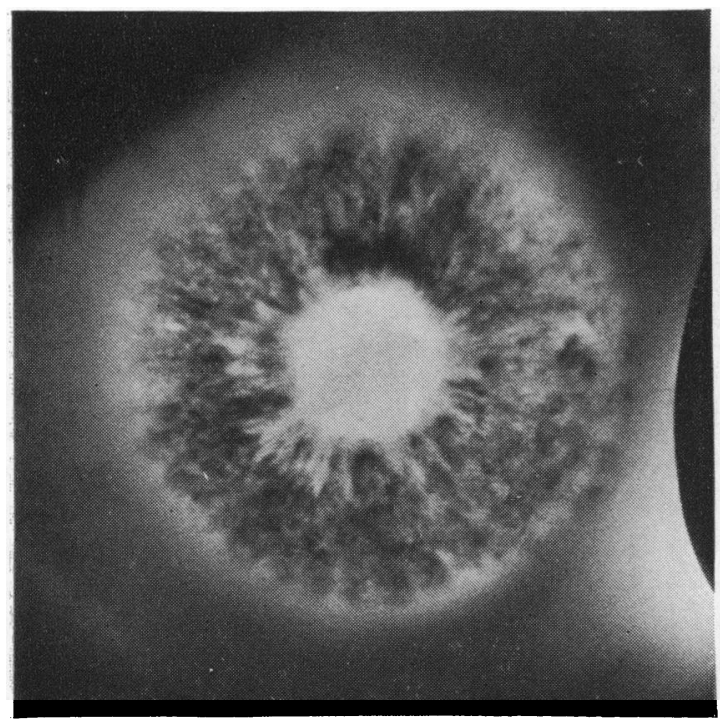

Fig. 4 (left) atrophic in 2 cases (57- and 71-year-old patients). The physiological senile atrophy in the contralateral normal eye was weak as compared with the widespread atrophy of the iris in FHC.

The sphincter muscle was atrophic in all eyes with FHC (Table 2). It was not visualised in infra-red transillumination stereophotographs of 6 eyes with extensive atrophy of the sphincter muscle. Seven eyes showed moderate changes with punctate (4 eyes), patchy ( 2 eyes), or radiate ( 1 eye) atrophy of the sphincter muscle. All contralateral eyes showed normal sphincter muscle except the case with coloboma of the iris.

Infra-red transillumination stereophotographs revealed on the posterior surface of the iris radial contraction folds of Schwalbe in 4 eyes with FHC and in 9 contralateral eyes (Table 2). Structural folds of Schwalbe were seen in 8 eyes with FHC and in all contralateral eyes, and circular contraction folds in 3 eyes with FHC and in 10 contralateral eyes.

\section{Discussion}

Infra-red transillumination stereophotography of the iris permits visualisation of the structural pattern of the stroma and posterior surface of the iris (Saari and Nieminen, 1976). In this study infra-red transillumination stereophotographs showed atrophy of the iris in all eyes with FHC. Extensive iris atrophy appeared as light, evenly translucent,

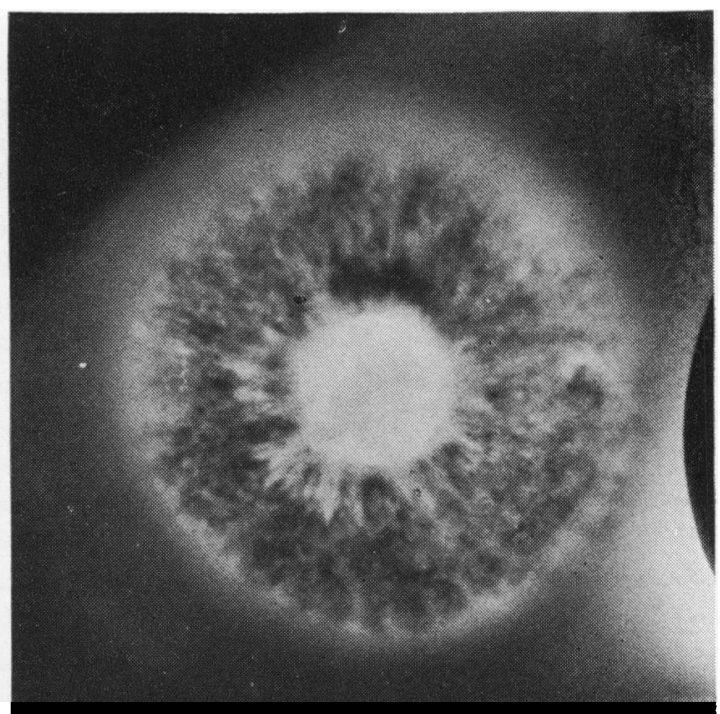

Fig. 4 (right)

Fig. 4 Infra-red transillumination stereophotographs of iris in FHC (case 7) showing extensive radiate atrophy of sphincter muscle and moth-eaten appearance of ciliary part 


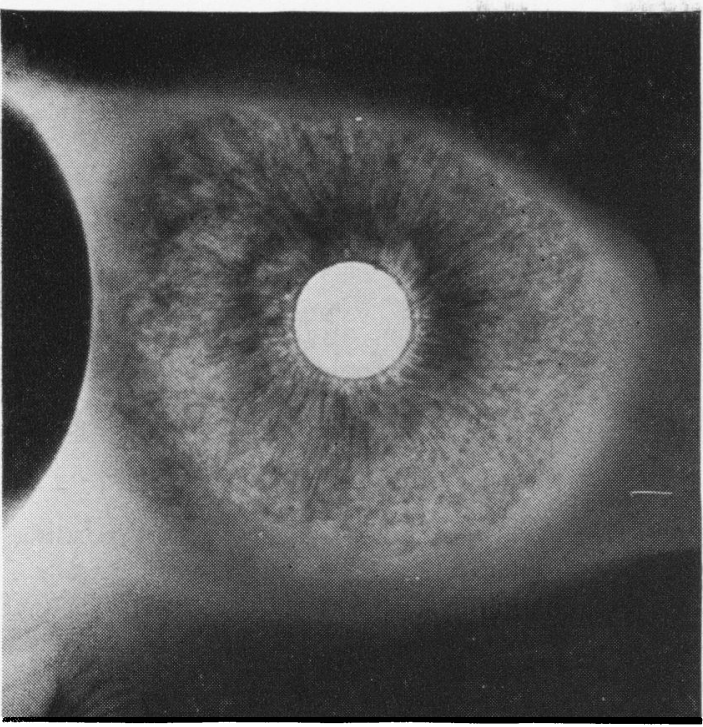

Fig. 5 (left)

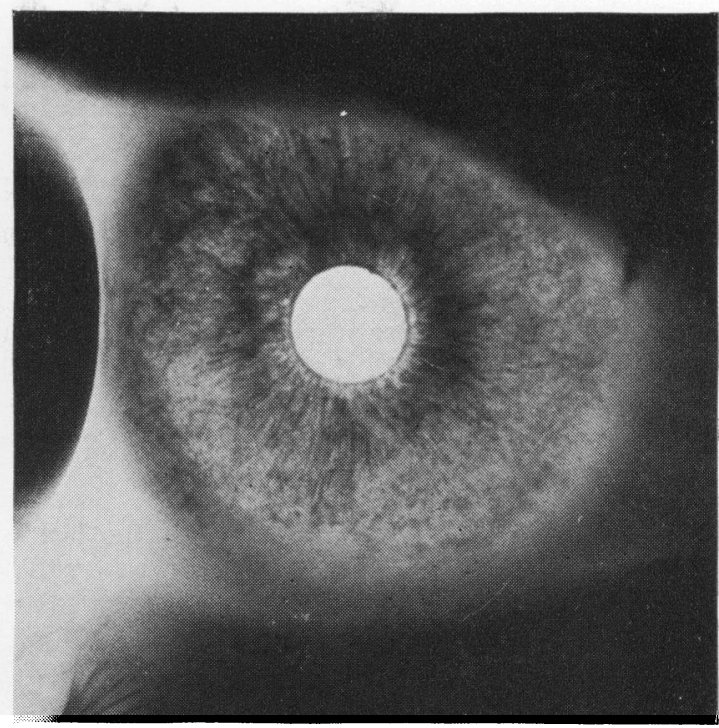

Fig. 5 (right)

Fig 5 Infra-red transillumination stereophotographs of iris in FHC (case 3) showing moderate radiate atrophy of sphincter muscle, and extensive atrophy with granular remnants in ciliary part

structureless pattern, scattered in some cases with occasional dense patches or pigment clumps. The sphincter muscle showed moderate changes with punctate, patchy, or radiate atrophy, or seemed to be totally atrophied. The present findings are in good agreement with histopathological studies on FHC showing atrophy depigmentation and sometimes pigment spots in the iris (Campinchi, 1973) and atrophic foci in the sphincter muscle or an entirely thinned and sclerosed sphincter (Loewenfeld and Thompson, 1973).

The structural pattern of the normal iris was rather dense in children, well developed in adults, and somewhat atrophic in the elderly subjects (Saari et al., 1977), as was seen also in this study in the normal contralateral eye. Physiological presenile or senile iris atrophy may involve the entire iris, causing a change in the iris colour, show pigment clumps in the superficial stroma, and be associated with ordinary senile cataract (Berliner, 1949). We found in this study that the iris atrophy was, however, much more extensive in the eye with FHC than in the contralateral eye with physiological senile iris atrophy.

Severe iritis may cause postinflammatory heterochromia and extensive iridic stromal atrophy in the sectors where the lesion has been most intense (Berliner, 1949). The results of this study show that the atrophic changes in FHC occur in the entire iris more uniformly.

Duke-Elder and Perkins (1966) paid attention to the difficulty of seeing depigmentation of the iris in the early stages of FHC. Some patients (cases 2, 10, and 12) in this study showed this clearly. Also in these cases the atrophic changes of the iris were seen with infra-red transillumination stereophotography, suggesting that this might be a useful diagnostic method in FHC.

This study was supported in part by the Medical Research Council of the Academy of Finland.

\section{References}

Berliner, M. L. (1949). Biomicroscopy of the Eye. Slit-lamp Microscopy of the Living Eye. Vol. 2, pp. 771-778, 849-868. Hoeber: New York.

Campinchi, R. (1973). Fuchs's heterochromic uveitis. In: Uveitis, Immunological and Allergic Phenomena, pp. 586597. Edited by R. Campinchi, J. P. Faure, E. BlochMichel, and J. Haut. Thomas: Springfield.

Duke-Elder, S., and Perkins, E. S. (1966). Diseases of the uveal tract. In System of Ophthalmology, Vol. 11, pp. 594-602. Edited by S. Duke-Elder. Kimpton: London .

Fuchs, E. (1906). Ueber Komplikationen der Heterochromie. Zeitschrift für Augenheilkunde, 15, 191-212.

Loewenfeld, I. E., and Thompson, H. S. (1973). Fuchs's heterochromic cyclitis: a critical review of the literature. I. Clinical characteristics of the syndrome. Survey of Ophthalmology, 17, 394-457.

Saari, M., and Nieminen, H. (1976). Fluorescein angiography and infra-red transillumination stereo technique for studying the ciliary body and iris. 5th Congress of the European Society of Ophthalmology, 5-9 April 1976, Hamburg.

Saari, M., Vuorre, I., and Nieminen, H. (1977). Infra-red transillumination stereophotography of normal iris. Canadian Journal of Ophthalmology, 12, 308-311. 